\title{
Low Birth Weight as Risk Factor of Pneumonia Child in Primary Health Care of Surabaya
}

\author{
Vania Ayu Puspamaniar ${ }^{1}$, Retno Asih Setyoningrum² ${ }^{\star}$, Dwi Susanti ${ }^{3}$
}

${ }^{1}$ Faculty of Medicine, Universitas Airlangga, Surabaya, Indonesia.

${ }^{2}$ Department of Paediatrics, Faculty of Medicine, Universitas Airlangga - Dr. Soetomo General Hospital, Surabaya, Indonesia.

${ }^{3}$ Department of Public Health and Preventive Medicine, Faculty of Medicine, Universitas Airlangga, Surabaya, Indonesia.

\section{A B S T R A C T}

Introduction: Pneumonia is an infectious disease attacking lower respiratory tract. It has one of the highest number of world's mortality and morbidity in children. Many risk factors are suspected as the reasons why the disease still occur a lot. One of the major risk factors is birth weight which makes their immune system immature and easier to get various complications and infections. The aim of this study is to analyze birth weight as risk factor of pneumonia in children under 5 years old.

Methods: This was an analytical study with case control design. This study was held in Primary Health Care of Tambakrejo, from August to December 2017. The sample size was 22 respondents for each case and control group. Technique of sampling was total sampling. Secondary data were collected by medical records at the health center and Kartu Menuju Sehat (KMS). Data were entered into Microsoft Excel then statistically analyzed using IBM SPSS 22 . The data were analyzed by Fisher's Exact Test.

Results: During August to December 2017, there were 22 respondents which were diagnosed with pneumonia in Tambakrejo Primary Health Center. Two of them $(4.55 \%)$ had low birth weight and the rests had normal birth weight $(95.45 \%)$. The analyze result stated that there is no significant correlation between pneumonia incidence and birth weight.

Conclusion: Birth weight is one of pneumonia risk factors without significant impact.

\footnotetext{
*Correspondence: retno-a-s@fk.unair.ac.id

JUXTA: Jurnal IImiah Mahasiswa Kedokteran Universitas Airlangga

p-ISSN: 1907-3623; e-ISSN: 2684-9453

DOI: 10.20473/juxta.V10I22019.61-62
}

Open access under Creative Commons Attribution-ShareAlike 4.0 International License

(CC-BY-SA)

\section{ARTICLE INFO}

\section{Article history:}

Received 09 August 2018

Received in revised form 19 August 2018

Accepted 27 August 2018

\section{Keywords:}

Pneumonia child,

Risk factors,

Birth weight. 


\section{Introduction}

Pneumonia is an infection disease attacking lower respiratory tract. This is one of the cause of high childhood mortality and morbidity in the world. World Health Organization explains that there are five leading causes of children mortality under five years, which are birth complication, pneumonia, asphyxia, diarrhea, and malaria. ${ }^{1}$ In Indonesia, the number of pneumonia occurrence is in second place after diarrhea, which is amounted $2.7 \%{ }^{2}$ There had been increased scope of pneumonia in toddler in Indonesia since 2008 to 2014 and there was significant increase in 2015 and 2016. Based on age group of population, high period prevalence of pneumonia occurred in age of 1-4 years. In 2017, East Java was in second place in national number of pneumonia in children 1-4 years, which were amounted $46.749 .^{2}$ Based on the data from Health Department of Surabaya in 2015, Surabaya has 4,018 cases of toddlers who suffered pneumonia. ${ }^{3}$

The high numbers of children with pneumonia are caused by several risk factors from either host, agent, or environment which are needed to be known and identified. Indonesian Government has conducted many efforts to detect and decrease the cases of toddlers with pneumonia early, such as the application of Manajemen Terpadu Balita Sakit (MTBS) which focuses on toddler's health and Pekan Imunisasi Nasional (PIN) that makes serious effort to enhance toddlers immunity. However, the effort has not been able to decrease toddlers with pneumonia in Surabaya. Many risk factors are being considered in determining number of pneumonia in toddler, such as malnutrition, low birth weight, non-exclusive breastfeeding, indoor air pollution, house density, having parents who smoke, Zinc deficiency, mother's parenting experience, accompanying disease, mother's education, presence of caregivers, air humidity, Vitamin A deficiency, birth order, and outdoor air pollution.

Low birth weight as one of the major's risk factors has such an impact to the occurance of pneumonia in children. Due to the immature immune system and organ formation, it makes them easier to get the infection.

\section{Methods}

This was an analytical study with case control design. Population in this research was all toddlers who lived in the area of Tambakrejo Primary Health Care in the period of August to December 2017. There were 22 toddlers for case group and 22 toddlers for control group. Thus, taking sample was conducted with purposive sampling technique. Criteria for case group was those who are under 5 years old and were pneumonia-diagnosed by the doctors in Tambakrejo Primary Health Care. Criteria for control group was those who are under 5 years old and were not pneumonia-diagnosed when visiting Tambakrejo Primary Health Care. This primary health care was chosen because it had the highest number of children with pneumonia in Surabaya in 2015.

Variable in this research was birth weight. The data were obtained through medical record and KMS. Data were entered into Microsoft excel then statistically analyzed using IBM SPSS 22. Data collected in this research were name, gender, date of birth, and birth weight.

\section{Results}

The research was conducted in August to December 2017 toward 44 respondents. There were two respondents who had low birth weight (4.55\%) and 42 respondents with normal birth weight $(95.45 \%)$. The characteristics of respondents are presented in Table 1 . Table 2 shows the result of birth weight's analysis. The $p$-value is one, which means there is no significant correlation between pneumonia incidence and birth weight.

Table 1. Characteristics of Respondents in Tambakrejo Primary Health Care in August to Desember 2017.

\begin{tabular}{|c|c|c|c|c|}
\hline No & Characteristics & $\begin{array}{l}\text { Case } \\
\mathrm{n}(\%) \\
\mathrm{N}=22\end{array}$ & $\begin{array}{l}\text { Control } \\
\mathrm{n}(\%) \\
\mathrm{N}=22\end{array}$ & $\begin{array}{l}\text { Mean } \pm \\
\text { SD }\end{array}$ \\
\hline 1. & $\begin{array}{l}\text { Age } \\
0-12 \text { months } \\
13-60 \text { months }\end{array}$ & $\begin{array}{l}9(40.9) \\
13(59.1)\end{array}$ & $\begin{array}{l}0(0) \\
22(100)\end{array}$ & $\begin{array}{l}29.36 \pm \\
15.41\end{array}$ \\
\hline 2. & $\begin{array}{l}\text { Sex } \\
\text { Male } \\
\text { Female }\end{array}$ & $\begin{array}{l}12 \\
(54.55) \\
10 \\
(45.45)\end{array}$ & $\begin{array}{l}10 \\
(45.45) \\
12 \\
(54.55)\end{array}$ & - \\
\hline 3. & $\begin{array}{l}\text { Birth Weight } \\
\text { Normal } \\
\text { Low }\end{array}$ & $\begin{array}{l}21 \\
(95.45) \\
1(4.55) \\
\end{array}$ & $\begin{array}{l}21 \\
(95.45) \\
1(4.55)\end{array}$ & $\begin{array}{l}3,484.1 \\
\pm \\
2,583.2\end{array}$ \\
\hline
\end{tabular}

Table 2. Fisher's Exact Test's Result.

\begin{tabular}{llll}
$\begin{array}{l}\text { Birth } \\
\text { Weight }\end{array}$ & $\begin{array}{l}\text { Case } \\
\mathbf{n}(\%)\end{array}$ & $\begin{array}{l}\text { Control } \\
\mathbf{n}(\%)\end{array}$ & $\begin{array}{l}\text { P } \\
\text { value }\end{array}$ \\
\hline Normal & $21(95.45)$ & $21(95.45)$ & Ref \\
\hline Low & $1(4.55)$ & $1(4.55)$ & 1,000 \\
\hline
\end{tabular}

\section{Discussion}

This study showed that most of the respondents are 13 until 60 months old. This is inline with the study in Jakarta that showed $62.3 \%$ of their respondents were $>12$ until $<60$ months old. ${ }^{4}$ The result on Table 1 shows that most of the respondents have normal birth weight and there is no correlation between pneumonia and birth weight. A study in Kenya about pneumonia risk factors revealed that most of their respondent had normal birth weight. ${ }^{5}$ There were also studies in Padang and Kenya that said there was no significant correlation between birth weight and pneumonia in children. ${ }^{5,6}$ Patria also said that most of researches had non significant result for birth weight. ${ }^{7}$ Nevertheless, a study in Iran showed a significant result between decreased mortality from pneumonia with increasing birth weight. ${ }^{8}$ Another study in India also said that there was a significant correlation between pneumonia in children and low birth weight as risk factor. ${ }^{9}$ The unsignificant result of the research might be caused by the sample size that was not enough to represent Surabaya.

Low birth weight infants had more risk to suffer from acute respiratory infection. ${ }^{10}$ In infants with low birth weight, there was immature immune system and body organs 
formation. It made infants with low birth weight easier to get various complications and infections. ${ }^{11}$ Low birth weight is included in factors that increase the risk of pneumonia in toddler. ${ }^{12}$ Risk of infant mortality with low birth weight in first months of life is very high because of the poor immune system so that they are easier to be infected including pneumonia. ${ }^{13}$

Limitation that could exist in this study is the size of sample that was too small so it could not represent Surabaya.

\section{Conclusion}

The classical risk factors such as birth weight was not associated with pneumonia in the study population. Some suggestions might be eligible for mothers such as maintaining their nutritional pregnancy, doing healthy life style, and checking their pregnancy up in the doctor regularly. In doing these, it can minimize the risk of low birth weight in infants.

\section{Acknowledgement}

1. The health workers at Tambakrejo Primary Health Care, Surabaya.

2. The workers at BAKESBANGPOL Surabaya and Dinas Kesehatan Surabaya.

\section{CONFLICT OF INTEREST}

The author stated there is no conflict of interest in this study.

\section{REFERENCES}

1. Organization WH. Pneumonia \& Diarrhea Progress Report: Reaching Goals Through Action and Innovation. Baltimore: Johns Hopkins Bloomberg School of Public Health, 2016.

2. Indonesia BPdPKKKR. Riset Kesehatan Dasar: Riskesdas 2013. Jakarta: Kementerian Kesehatan Republik Indonesia, 2013.

3. Surabaya DKK. Profil Kesehatan Kota Surabaya Tahun 2015. Surabaya: Dinas Kesehatan Kota Surabaya, 2015.

4. Hartati S, Nurhaeni N and Gayatri D. Faktor Risiko Terjadinya Pneumonia pada Anak Balita. 2012. 2012; 15: 8.

5. Asbjornsdottir $\mathrm{KH}$, Slyker JA, Weiss NS, et al. Breastfeeding is associated with decreased pneumonia incidence among HIV-exposed, uninfected Kenyan infants. AIDS (London, England). 2013; 27: 2809-15.

6. Efni $Y$, Machmud $R$ and Pertiwi D. Faktor Risiko yang Berhubungan dengan Kejadian Pneumonia pada Balita di Kelurahan Air Tawar Barat Padang. Jurnal Kesehatan Andalas. 2016; 5: 365-70.

7. Patria MA. Faktor Risiko Pneumonia pada Balita di Indonesia: Narative Review Penelitian Akademik Bidang Kesehatan Masyarakat. Jurnal Kesehatan Masyarakat. 2016; 10: 57-62.

8. Fonseca Lima EJd, Mello MJG, Albuquerque MdFPMd, et al. Risk factors for community-acquired pneumonia in children under five years of age in the postpneumococcal conjugate vaccine era in Brazil: a case control study. BMC pediatrics. 2016; 16: 157-.
9. Gothankar J, Doke P, Dhumale G, et al. Reported incidence and risk factors of childhood pneumonia in India: a community-based cross-sectional study. BMC public health. 2018; 18: 1111.

10. Kartasasmita CB. Pneumonia Pembunuh Balita. Buletin Jendela Epidemiologi. 2010; 3: 22-6.

11. Indonesia KKR. Pneumonia Balita. Jakarta: Pusat Buletin Jendela Epidemiologi, 2010.

12. Rudan I, Boschi-Pinto C, Biloglav Z, Mulholland K and Campbell $\mathrm{H}$. Epidemiology and etiology of childhood pneumonia. Bulletin of the World Health Organization. 2008; 86: 408-16.

13. Imelda. Hubungan Berat Badan Lahir Rendah dan Status Imunisasi dengan Kejadian Infeksi Saluran Pernafasan Akut pada Balita di Aceh Besar. Jurnal IImu Keperawatan. 2017; 5: 91-6. 